\title{
A Comparative Study on the Customers' Motivation to Deal with E-Commerce through E-Banking Services in Saudi Islamic and Conventional Banks
}

\author{
Mohammed Naif Alotaibi (Corresponding Author) \\ Taif University, College of Admin and Financial Sciences, Taif, Saudi Arabia \\ Email: muhamednaef@gmail.com \\ Professor Mehmet Asutay \\ Professor of Middle Eastern and Islamic Political Economy \& Finance \\ Durham University Business School, Durham, UK \\ Email: mehmet.asutay@ durham.ac.uk
}

Doi:10.5296/ jpag.v5i3.8221 URL: http://dx.doi.org/10.5296/ jpag.v5i3.8221

\begin{abstract}
Purpose - The aim of this paper is to investigate the customers' motivation to deal with e-commerce through e-banking services according to the perceptions of their customers.

Design / methodology / approach - This paper presents the initial findings with the objective of developing an efficient understanding of customers' preferences based on their opinions and perceptions expressed through a questionnaire survey.

Findings - The findings are based on a sample of 198 customers and indicate that the majority of the respondents from both types of banks tend to be equally motivated to deal with e-commerce through e-banking services. The paper also finds that both groups of banks encourage their customers to deal with e-commerce using facilities in Saudi banks.

Research limitation / implications - The study has considered only six banks out of the total of 12 in Saudi Arabia. In addition, the research is based on a limited selection of bank customers in three main regions of Saudi Arabia, covering $65.5 \%$ of the Saudi population.

Practical implications - With reference to practical implications, the findings suggest that the customers' motivation to deal with e-commerce through e-banking services can play an essential role in expanding dealing with e-commerce in Saudi Arabia.
\end{abstract}

Originality/value - This is the first paper in the area of customers' motivation to deal with 
e-commerce through e-banking services on a comparative analysis of Islamic and conventional banks in Saudi Arabia. The findings and implications of the research offers invaluable information to the industry and policy-makers.

Keywords: Motivation, E-commerce, E-banking, Islamic Banks, Conventional Banks.

\section{Introduction}

With technological development, the way we conduct our economic and financial affairs has changed. The extensive use of technology by banks and financial institutions aims to respond to customers' demands by providing efficient, fast and convenient financial services. The extensive use of e-banking services has also expanded into e-commerce areas. Inevitably, this has been the case with the majority of banks including Islamic banks in the GCC region. With the help of globalisation and technology, businesses all over the world are now seen to be taking advantage of expanded e-commerce activities (Kolsaker and Payne, 2002). Similarly, small and medium sized businesses are obtaining rapid growth by using e-commerce as a strategy (Grandónet al., 2011).

The issues of these rapid changes are threatening electronic markets as well as e-commerce business oriented aspects. The businesses over time have been advantaged through IT by having access to number of goods and services twenty-four hours(CITCIT Report, 2010). The Internet and World Wide Web (www) has driven e-commerce to become one of the most significant areas in the twenty-first century (Yasen and Al-alaq, 2009).

Considering the size and the nature of the Saudi Arabian economy, it is true that e-commerce has a long way to go: online purchases in 2010 are estimated at $6 \%$ as compared to $13 \%$ in the Czech Republic and $58 \%$ in the USA. Nonetheless, online shopping is becoming popular among internet users in Saudi Arabia, and the future looks promising for the business (CITCIT Report, 2010).According to European Travel Commission (2014), the Internet users in Saudi Arabia are8.5 million users with 60\% of population in 2014 (http://etc-digital.org/). In addition, the internet penetration in Saudi Arabia is 49\% (www.nielsen.com, 2014).

This paper is organised in six sections. Section 2 presents a brief overview of banking sector, e-commerce and e-banking in Saudi Arabia. Section 3 presents a brief literature review on e-commerce through e-banking in order to establish a foundation for this study. Section 4 presents the research methodology and process, while section 5 presents the summary and the characteristics of sample profile on customers' motivation. Section 6presentsthe initial descriptive statistical and inferential analysis findings about the customers' motivation to deal with e-commerce through e-banking services. Finally, section 7 provides a brief discussion and completes the paper with some concluding remarks.

\section{An Overview of Banking Sector, E-Commerce and E-Banking in Saudi Arabia}

Saudi Arabia has twelve banks and the Saudi Arabian Monetary Agency (SAMA) is the Central Bank of Saudi Arabia; and is an autonomous body and independent body. In addition to domestic banks, there are several foreign banks, which operate in Saudi Arabia. This paper, 


\section{MInstitute Macrothink $_{\text {Int }}$}

Journal of Public Administration and Governance

ISSN 2161-7104

2015, Vol. 5, No. 3

however, only focuses on Saudi Arabian domestic banks, as they have much greater networks of branches than the foreign bank. In simple terms, SAMA implements the laws and standards for all the banks and provides the necessary regulatory environment (SAMA Annual Report, 2011). Table 1 shows the details of Saudi Islamic and conventional banks, including information on branches, online-banking, call-centre, ATMs, POS and capital.

Table 1: Details of the Saudi banks within Saudi Arabia

\begin{tabular}{|c|c|c|c|c|c|c|c||}
\hline Bank & Branches & Online-Banking & Call-centre & ATM & POS & Capital (SARbn) \\
\hline \hline \multicolumn{7}{|c||}{ Islamic Banks } \\
\hline \hline Al-Bilad & 102 & $\checkmark$ & $\checkmark$ & 829 & 925 & 4 \\
\hline Al-Inma & 55 & $\checkmark$ & $\checkmark$ & 1000 & N.A & 15 \\
\hline Al-Jazira & 66 & $\checkmark$ & $\checkmark$ & 308 & N.A & 4 \\
\hline Al-Rajhi & 500 & $\checkmark$ & $\checkmark$ & 3600 & 28000 & 16.250 \\
\hline \hline \multicolumn{7}{|c|}{} & \multicolumn{7}{|c|}{ Conventional Banks } & $\checkmark$ & 2542 & 10713 & 30 \\
\hline \hline Al-Riyad & 318 & $\checkmark$ & $\checkmark$ & 1200 & 11000 & 10 \\
\hline Arab National & 203 & $\checkmark$ & $\checkmark$ & $\checkmark$ & 2252 & 23000 & 20 \\
\hline NCB & 329 & $\checkmark$ & $\checkmark$ & 512 & 5381 & 12 \\
\hline Samba & 68 & $\checkmark$ & $\checkmark$ & 510 & 7069 & 10 \\
\hline Saudi British & 80 & $\checkmark$ & $\checkmark$ & 576 & 8634 & 12.05 \\
\hline Saudi Fransi & 83 & $\checkmark$ & $\checkmark$ & 265 & 7190 & 4.76 \\
\hline Saudi Hollandi & 44 & $\checkmark$ & $\checkmark$ & 324 & 154 & 6 \\
\hline Saudi Investment & 45 & $\checkmark$ & & & \\
\hline
\end{tabular}

Source: www.cdsi.gov.sa/,Bankscope Database (2015) and SAMA annual report (2013).

In fact the link between e-commerce and e-banking services is very clear and important; without e-payment e-commerce would not be possible (Al Saud and Abdallah, 2004). According to Al-Somali et al. (2009) Saudi Arabia is a regional leader in relation to Internet banking. Moreover, SAMA (2013) Saudi Arabia ranks at the top in the field of information technology amongst the Arabian states. In addition, a market study by CITC (2010) found that $82 \%$ of Saudis used online banking services. It was noted that the majority of account holders used services such as account balance enquiries, paying bills, and transfers between banks (see: www.citc.gov.sa). Furthermore, Bahaddad et al. (2013)stated that 54\% of Saudi companies have websites to present their products.

In further providing evidence, Al-Somali et al. (2011) conducted research about the Saudi SMEs' adoption of e-commerce, which showed that the level of adoption of e-commerce has not reached to the level of maturity. The results stress that there is a need to improve internet shopping in Saudi SMEs. Furthermore, Elseoud (2014) focused on national economic growth from 2001- 2013 and found that there is a need to increase investment in the infrastructure, to have more users of the internet, and to offer more credit cards to the users in Saudi Arabia.

Table 2 shows the growth of internet usage in Saudi Arabia. As can be seen in 2002, only 6\% of the population had access to internet, which reached to $66.9 \%$ at 2014 . This clearly 
suggests that the public was encouraged to use the facility.

Table 2: Internet Growth in Saudi Arabia, 2002-2014

\begin{tabular}{|c|c|c|c||}
\hline Year & Internet Users & Population & Penetration Rate \\
\hline 2002 & $1,400,000$ & $21,494,813$ & $6 \%$ \\
\hline 2005 & $3,000,000$ & $23,329,584$ & $13 \%$ \\
\hline 2008 & $9,300,000$ & $25,787,025$ & $36 \%$ \\
\hline 2011 & $13,600,000$ & $28,376,355$ & $48 \%$ \\
\hline 2014 & $20,070,000$ & $30,000,000$ & $66.9 \%$ \\
\hline
\end{tabular}

Sources: www.cdsi.gov.sa/, www.citc.gov.sa, www.Internet.gov.sa, and www.internetworldstats.com/

\section{Conceptual and Empirical Literature Review}

There are several definitions offered about e-banking and e-commerce. Al-Wadi et al (2010:109) defines e-banking as banks which fully operate via the internet. Those banks are known as virtual banks where all transactions take place electronically rather than face to face. The Saudi Arabian Monetary Agency (SAMA) defines e-banking as electronic banking services that feature distance services provided by sanctioned banks or their representatives through systems directly controlled by the appropriate bank or otherwise by another body in accordance with the terms of an agreement between the two sides (SAMA, E-Banking Rules, 2010).

Similar to any other social science subject, controversy can be observed here as well. Regardless of such differences, definitions of e-commerce are based upon the values. Chaffey, (2009:10) defines E-commerce as "all electronically mediated information exchanges between an organization and its external stakeholders". Bidgoli (2002:45) defines e-commerce as purchasing and sale merchandise and services by the Internet. In an institutional manner, The Organisation for Economic Co-operation and Development(OECD) defines e-commerce as "the sale or purchase of goods or services, conducted over computer networks by methods specifically designed for the purpose of receiving or placing or orders" (OECD, 2011: 72). Since its evolution in 1970s, e-commerce has developed rapidly involving a number of distinct stages. In its early stages of development, however, the internet featured a package of communication discipline compiled by Leiner et al.,(2009) as part of a programme sponsored by the US Department of Defence. Eventually, the first internet activity emerged in 1973 and fully developed in 1983.

Kalakota and Whinston (1997) argue and clearly note that the earlier media links could not cut the long distances in between the media and end users. The early 1920s witnessed the emergence of radio way of introducing; TV was introduced in 1950s, and was not in line to send the message to the large populations. The video and its links were introduced in 1970s, and computer in 1980s. However this is not as the media links failed to target maximum. Suh and Han (2003) revealed that the internet users were reluctant to share personal information to the Web sites due to security issues. The scholars during their investigation focused perceptions of the customers about e-commerce acceptance. The statistical analysis of 502 
cases showed that privacy protection had a significant impact in trusting e-commerce.

Mezian and Kasiran (2008) inferred that the customers while are asked online to provide their details, they normally decline and do not go ahead in processing their transactions. Therefore a model was developed in EC trust, and the application of such model is bringing back confidence in among the customers. However, the issue is there, and needs to managed through technology at the least. Maslow's theory of needs clearly addresses and argues that people need food, shelter, affection, esteem and self-development. In simple terms, people's needs are limitless, and these are growing very fast, and that the media is playing a big role in creating these needs and wants. Their job is becoming quite demanding, as the technologies are changing and with the changing scenarios, these requirements are increasing. Though the customers' needs are broad, and wants usually narrow, perhaps (Conley, 2007).

Chan et al., (2001) further indicated that web enabling services now helping the users in banking, stock trading and education, while match making services are providing assistance in job, travel, insurance and etc, whereas entertainment services are being used while the users wanted to watch movies, electronic games. Customers' satisfaction is important while judging the efficiency of any new technology. Though e-service is now the little old concept in the western world, but this still new in the developing countries. In a study, Where Kumbhar (2011) gathered data from the customers of e-banks through a survey questionnaire. The results indicate that majority regarded cost effectiveness, easy to use, problem handling, security assurance and they were satisfied with the use e-banking. While contact facilities and system efficiency were the least concerns compared to the majority. However, the overall customers were found to be aware of and accepted the advantages of e-banking in India.

Ben-Jadded and Molina (2004) have highlighted the role of online banking in a bank called Samba in Saudi Arabia. This is a bank which is represented by group different stakeholders. The results clearly showed that the bank is using all external technologies to make their customers satisfied. It is also worthwhile to see that initially Samba group installed 24/7 ATMs in the different cities in the whole country. Sohail and Sheikh (2008) conducted a research in Saudi Arabia, where the data were obtained from the banks. The issue was how banks provided online banking along with the role of services. The results of this research showed that there were four factors which had an impact such as efficiency, security, fulfilment and responsiveness. The impact of each service might be different than others. The online banking is practiced worldwide now, a similar research was conducted in the banking sector in Saudi Arabia.

Similarly, Al-Somali et al.,(2009) though accepted Saudi Arabia as a leader in the region for Internet banking, they recognize that it should do more in improving customer relationships and especially in cost savings. The developed model was tested in among the 400 customers for the factors that are Internet quality, awareness to online banking, social influence and computer efficacy. The results indicated that the pre-mentioned factors had significant effects in the functioning of online-banking in among the customers. 


\section{Research Methodology and Data Collection}

The data for this study has been collected from a questionnaire which was distributed to customers of both Islamic and conventional banks. The collected data were subjected to statistical analysis through statistical package for social sciences (SPSS), version 20. The calculations were drawn statistically for descriptive statistics such as means, standard deviations, frequencies, including ranking of various questions. The means were implied to know the understanding of respondents in both the banks such as conventional banks and Islamic banks.

Sample selection out of a large population constitutes a crucial part of any social science research. A sample is selected to adequately represent the population at large. Sampling must be based on some logical criteria; but in the absence of such order, random selection is highly advised. Ideally, sample selection must be made through different stages (Oliver, 1964). These stages are sometimes referred to as "strata" or layers. Normally, the first stage relates to the identification of the "target" population. Whilst population represents the total set of elements, the target population is a small part of the population identified to represent the whole population (Hair et al, 2000). Once the target population is identified, the next stages/strata can be based on researcher's choice on, say, sex, race, income, size of household, location and any other relevant socio-economic indicators (Scheaffer, et al, 2012).

Questionnaire in this study was designed in association with the literature on e-commerce and e-banking services and the research question. This research includes the 'Neutral' responses as very important. On the one hand, this suggests that the policy makers were not right in implementing their policies. While on the second hand, the policy makers can get a way to change their managerial roles. Finally, the respondents' understandings, perceptions and customers' motivation were tested through the survey questionnaire to gather quantitative data. After a careful consideration, 6 main questions were chosen in relation to the customers' motivation to deal with e-commerce through e-banking services in Saudi Arabian Islamic and conventional banks, based on Likert scale (1-5), as follows:

(i) The ease of the use of e-services motivated me to switch over to e-commerce;

(ii) The $24 / 7$ availability of e-services and e-commerce motivated me to switch over to e-commerce;

(iii)Website design of Bank motivated me to use Internet Banking;

(iv)Changing nature of shopping as a life style necessitates the use e-banking services and e-commerce;

(v) E-Payment method encouraged me to adopt e-commerce;

(vi)Banks provide Information to their customers about the use of online Banking, ATMs and others.

In order to improve the consistency and effectiveness of the findings, it is intended that a relatively large sample size of banks customers will be considered. For the purpose of 


\section{Al Macrothink}

time-saving and efficiency, a detailed questionnaire was designed and distributed. The survey questionnaire was administrated during May-July, 2012. Instead of focusing on the respondents in the banks' branches, the researcher used different approach. It is believed that the customers who were using e-banking services would not normally visit the branch. Therefore, friends, colleagues, and others were given survey questionnaire to distribute among the users of e-banking service that they were aware of. The respondents come from different cities such as Riyadh, Alkarj, Jeddah, Makkah, Taif, Dammam, and Alkubr. Through this scheme, 250 questionnaires were distributed (125 each in Islamic and conventional banks). The whole process of distribution to collection of questionnaire took nearly three months.

The researcher was available in Saudi Arabia for answering any possible questions raised by the respondents. By the end of August 2012, all the total 250 questionnaires were received, but 52 of them were excluded due to non-completion. It means there were 198 questionnaires with complete information ready for data analysis. Finally, the issues relating to informed consent and confidentiality of the information within the framework of academic ethics were followed throughout the survey. Table 1 illustrates the response rate of questionnaire for both Islamic and conventional banks.

Table 1: The Response Rate of Questionnaire

\begin{tabular}{|l|l|l|l|}
\hline Types of Banks & Distributed & Received & $\%$ Completion \\
\hline Islamic & 125 & 104 & $83.2 \%$ \\
\hline Conventional & 125 & 94 & $75.2 \%$ \\
\hline Total & 250 & 198 & $79 \%$ \\
\hline
\end{tabular}

After the collection of primary data through questionnaire, Cronbach's Alpha Test is used to measure internal consistency reliability and one of the most regularly used statistics. The Cronbach alpha value of at least 0.70 is the basis of reliability (Cronbach, 1951) and thus the 0.70 alpha value is the way to judge the consistency of the variables, and how these variables attribute (Fujunet al. 2007). Hence in this study, Cronbach alpha value were .954 and .888 for Islamic and Conventional banks respectively as shown in Table 2 that qualifies the base of testing the attributes as being reliable and preferable. 


\section{Macrothink}

Table 2: Reliability Statistics (Cronbach's Alpha Coefficient) for Islamic and Conventional Banks

\begin{tabular}{|l|l|l|l|}
\hline \multirow{2}{*}{ Factor } & \multirow{2}{|c|}{ N of Items } & \multicolumn{2}{|l|}{ Cronbach's Alpha } \\
\cline { 3 - 4 } & Islamic Banks & $\begin{array}{l}\text { Conventional } \\
\text { Banks }\end{array}$ \\
\hline $\begin{array}{l}\text { The motivation to deal with } \\
\text { e-commerce through } \\
\text { e-banking }\end{array}$ & 6 & .910 & .850 \\
\hline
\end{tabular}

\section{The Characteristics of Sample Profile}

This section displays the summary of sample profile that was under investigation, based on type of bank, frequency, sub-total of cumulative total, and cumulative total for Islamic Banks: Alinma, Al-Jazera and Al-Rajihi; and Conventional Banks: Arab National, Saudi Fransi and Samba. Table 3 shows that the total number of the respondents is 198 , where $52.5 \%$ of the respondents represented the Islamic banks and $47.4 \%$ were from Conventional banks.

Table 3: Profile of the Participants

\begin{tabular}{|l|l|l|l|}
\hline Islamic Banks & Frequency & \%Sub-Total & $\begin{array}{l}\text { \% } \\
\text { Cumulative } \\
\text { Total }\end{array}$ \\
\hline Alinma & 34 & 32.7 & 17.1 \\
\hline Al-Jazira & 30 & 28.8 & 15.1 \\
\hline Al-Rajhi & 40 & 38.5 & 20.2 \\
\hline Sub-Total & 104 & 100.0 & 52.5 \\
\hline $\begin{array}{l}\text { Conventional } \\
\text { Banks }\end{array}$ & 32 & 34.0 & 16.1 \\
\hline Arab National & 32 & 31.9 & 15.2 \\
\hline Saudi Fransi & 30 & 34.0 & 16.1 \\
\hline Samba & 32 & \multicolumn{2}{|l}{} \\
\hline
\end{tabular}




\begin{tabular}{|l|l|l|l|}
\hline Sub-Total & 94 & 100.0 & 47.4 \\
\hline Total & 198 & & 100.0 \\
\hline
\end{tabular}

The characteristics of the respondents in relation to their gender, nationality, age category, monthly income, highest educational qualifications, occupation and region from the samples are presented in table 4 . This further provides the variation in the groups and the category of the respondents. The percentages for each character are shown separately.

As can be seen in Table 4, 56.1\% of the participants in the research were males, while $43.9 \%$ were female. Considering the gender segregation in Saudi Arabia, this study should be considered successful in attracting a female sample of almost $44 \%$.

With regards to the nationality of the respondents, $67.7 \%$ of respondents were Saudi nationals and $32.3 \%$ non-Saudis. As for age distribution of the sample, the results in Table 4 shows that $70.7 \%$ of the sample population were aged 45 or below. More specifically, the largest percentage, $33.3 \%$, were in the 26-35 year old category, a further $26.8 \%$ were in the $36-45$ age group, and just $16.2 \%$ in the $46-55$ years age group. The $18-25$ years old category made up $10.6 \%$ and those over 55 years of age constituted only $13.1 \%$, with the mean value for the age category being 2.88 . This implies that the majority of respondents were young people, who are employed or run their own businesses.

The results for monthly income, highest educational qualifications and occupation are also shown in Table 4. In terms of monthly income, $62.6 \%$ of respondents earned within the range of SAR4,001 to SAR12,000, followed by those earning in the range of SAR12,001 to SAR16,000, which constitute $23.2 \%$ of the sample. The mean value calculated was 2.90 implying that the average income in the sample was somewhere between the two ranges of SAR4000-SAR12000 and SAR12001-SAR16000. As regards to educational qualifications, $51.5 \%$ of respondents declared that they had bachelor or master's degrees or above compared to $48.5 \%$ respondents who had high school education or lower level. The mean value calculated was 2.42 . 


\section{Macrothink

Table 4: Characteristics of the Respondents

\begin{tabular}{|c|c|c|c|c|}
\hline Variable Group & Frequency (Valid) & $\%$ (Valid) & Mean & $\begin{array}{l}\text { Standard } \\
\text { Deviation }\end{array}$ \\
\hline $\begin{array}{l}\text { Gender } \\
\qquad \begin{array}{l}\text { Male } \\
\text { Female }\end{array}\end{array}$ & $\begin{array}{c}111 \\
87\end{array}$ & $\begin{array}{l}56.1 \\
43.9\end{array}$ & 1.44 & 0.498 \\
\hline $\begin{array}{l}\text { Nationality } \\
\qquad \text { Saudi } \\
\text { Sudanese } \\
\text { Indian } \\
\text { Pakistani } \\
\text { Egyptian } \\
\text { Yemeni } \\
\text { Syrian } \\
\end{array}$ & $\begin{array}{c}134 \\
9 \\
9 \\
10 \\
13 \\
14 \\
9 \\
\end{array}$ & $\begin{array}{l}67.7 \\
4.5 \\
4.5 \\
5.1 \\
6.6 \\
7.1 \\
4.5 \\
\end{array}$ & 2.18 & 1.942 \\
\hline $\begin{array}{l}\text { Age category } \\
\qquad 18-25 \text { years } \\
26-35 \text { years } \\
36 \text { - } 45 \text { years } \\
46 \text { - } 55 \text { years } \\
\text { Over } 55 \text { years }\end{array}$ & $\begin{array}{l}21 \\
66 \\
53 \\
32 \\
26\end{array}$ & $\begin{array}{l}10.6 \\
33.3 \\
26.8 \\
16.2 \\
13.1\end{array}$ & 2.88 & 1.199 \\
\hline $\begin{array}{l}\text { Monthly income } \\
\text { Less than } 4001 \mathrm{SR} \\
4001 \text { - } 8000 \mathrm{SR} \\
8001 \text { - } 12000 \mathrm{SR} \\
12001 \text { - } 16000 \mathrm{SR} \\
16001 \text { - } 20000 \mathrm{SR} \\
\text { More than } 20000 \mathrm{SR}\end{array}$ & $\begin{array}{l}44 \\
46 \\
34 \\
46 \\
16 \\
12\end{array}$ & $\begin{array}{c}22.2 \\
23.2 \\
17.2 \\
23.2 \\
8.1 \\
6.1\end{array}$ & 2.90 & 1.491 \\
\hline $\begin{array}{l}\text { Highest educational } \\
\text { qualifications } \\
\text { Below High School } \\
\text { High School } \\
\text { Bachelor degree } \\
\text { Master degree or above }\end{array}$ & $\begin{array}{l}40 \\
56 \\
80 \\
22\end{array}$ & $\begin{array}{l}20.2 \\
28.3 \\
40.4 \\
11.1\end{array}$ & 2.42 & 0.935 \\
\hline 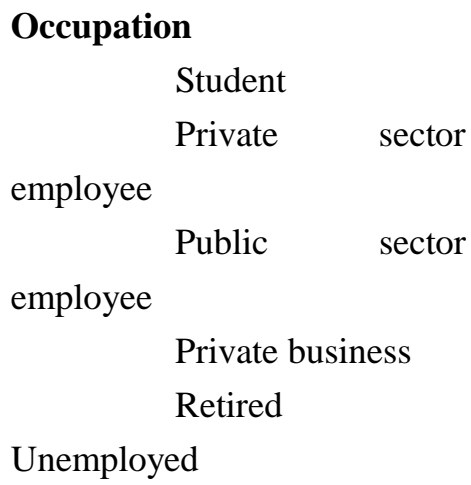 & $\begin{array}{c}18 \\
63 \\
90 \\
7 \\
11 \\
9\end{array}$ & $\begin{array}{c}9.1 \\
31.8 \\
45.5 \\
3.5 \\
5.6 \\
4.5\end{array}$ & 2.78 & 1.144 \\
\hline Region & & & 1.86 & 0.710 \\
\hline
\end{tabular}




\begin{tabular}{|c|l|l|l|l|}
\hline Riyadh Region & 65 & 32.8 & & \\
Western Region & 95 & 48.0 & & \\
Eastern Region & 38 & 19.2 & & \\
\hline
\end{tabular}

Concerning occupation, $45.5 \%$ of the sample came from public sector employment, with $31.8 \%$ from the private sector; $9.1 \%$ were students, followed by $5.6 \%$ retired and $3.5 \%$ being in private business, while the unemployed represented $4.5 \%$. The mean value was 2.78 , which means that the typical respondent was either a private or public employee. The final category in the study was region. Almost one-half of the respondents, $48.0 \%$, were from the Western region, followed by Riyadh with $32.8 \%$ and Eastern Region, with only $19.2 \%$, and the mean value was 0.710 .

In summary, it can be said that the majority of the respondents in each demographic were Saudi males, aged between 26-35, earning range being somewhere between SAR4,001-SAR8,000 and SAR12,001-SAR16,000 categories, with bachelor degrees as their highest educational qualifications, employed in the public sector and predominantly from the Western region.

\section{Empirical Findings}

This section aims to present the initial descriptive statistical findings about the customers' motivation to engage with e-commerce through e-banking services in Saudi Arabian Islamic and conventional banks. This includes analysing the responses given to a number of statements. The results can be seen in table 5 .

Table 5: Mean Ranking of Customers' Motivation to Engage with E-Commerce

\begin{tabular}{|c|c|c|c|c|}
\hline \multirow{2}{*}{ Statements } & \multicolumn{2}{|c|}{ Islamic Banks } & \multicolumn{2}{|c|}{ Conventional Banks } \\
\hline & Mean & Ranking & Mean & Ranking \\
\hline $\begin{array}{l}\text { 1) The ease of the use of e-services } \\
\text { motivated me to switch over to } \\
\text { e-commerce }\end{array}$ & 3.52 & 3 & 3.50 & 5 \\
\hline $\begin{array}{l}\text { 2) The } 24 / 7 \text { availability of e-services and } \\
\text { e-commerce motivated me to switch } \\
\text { over to e-commerce }\end{array}$ & 3.71 & 1 & 3.83 & 1 \\
\hline $\begin{array}{l}\text { 3) The website design of the bank } \\
\text { motivated me to use internet banking }\end{array}$ & 3.49 & 4 & 3.67 & 2 \\
\hline $\begin{array}{l}\text { 4) Changing nature of shopping as a life } \\
\text { style necessitates the use e-banking } \\
\text { services and e-commerce }\end{array}$ & 3.58 & 2 & 3.64 & 3 \\
\hline $\begin{array}{l}\text { 5) E-Payment method encouraged me to } \\
\text { adopt e-commerce }\end{array}$ & 3.71 & 1 & 3.54 & 4 \\
\hline $\begin{array}{l}\text { 6) Banks provide Information to their } \\
\text { customers about the use of online } \\
\text { Banking, ATMs and others }\end{array}$ & 3.40 & 5 & 3.38 & 6 \\
\hline
\end{tabular}




\section{Al Macrothink}

According to table 5, the results of assessing customers' motivation to engage with e-commerce by presenting the mean ranking results. As can be seen, in the case of both banking type, the customers have chosen the same preference order for only 1 of 6 statements, and for the rest the mean values are dissimilar.

In pursuing our investigation, the research has focused on the development of inferential statistical analysis based on the statistical significance of control variables in the answers provided by participants of the survey. These control variables are based on the demographic questions raised in the initial section of the questionnaire survey and they include the following categories: 'gender', 'nationality', 'age category', 'monthly income', 'highest educational qualifications', 'occupation' and 'region' with the group categories in sections of customer's motivation to engage with e-commerce through e-banking services in Saudi Arabian Islamic and conventional banks.

As for the deterministic factors of respondents' customer's motivation in e-commerce and e-services for Islamic and Conventional banks, non-parametric analysis was utilised, in which the inferential statistical results are fundamentally based on testing the differences between participants in relation to each control variable for the given answers to the questions through the use of non-parametric tests, including the Independent Samples Kruskal-Wallis Test (K-W Test) and the Mann-Whitney U Test (M-WU Test). The Kruskal-Wallis Test and Mann Whitney-U test for the control variables with the group categories of customer's motivation in e-commerce through e-services for Islamic and Conventional banks relating to question 1 to 6 are presented in tables 6-12, respectively.

Table 6 displays the results for the determining variables relation to the statement that 'The ease of the use of e-services motivated me to switch over to e-commerce', which shows that 'nationality', 'age category', 'highest educational qualifications', 'occupation' and 'region' are the statistically significant independent variables.

As can be seen from Table 6, in the case of Islamic banks, the control variables 'nationality', 'age category', 'highest educational qualifications', 'occupation' and 'region' are statistically significant at the level of 5\%, albeit with different $p$-values. In the 'nationality' control variable 'Sudanese' nationalities scored the highest mean value at 60.92 and the lowest mean rank is scored by the 'Indian' nationalities with a mean value of 27.75 and the $p$-value of 0.042.In the 'age category' control variable, the '18-25 year-olds' subgroup recorded the highest value at 67.50 and the lowest mean rank was for the subgroup 'over 55 year-old' with a value of 20.94. In this case, the $p$-value is 0.000 . 


\section{Ml Macrothink}

Table 6: Significance of Control Variables on the Statement: The ease of the use of e-banking services motivated me to switch over to e-commerce

\begin{tabular}{|c|c|c|c|c|c|c|}
\hline \multirow{2}{*}{$\begin{array}{c}\text { Group (Control } \\
\text { Variables) }\end{array}$} & \multirow{2}{*}{ Group Categories } & \multicolumn{2}{|c|}{$\begin{array}{c}\text { Islamic } \\
\text { Banks }\end{array}$} & \multicolumn{2}{|c|}{$\begin{array}{c}\text { Conventional } \\
\text { Banks }\end{array}$} & \multirow{2}{*}{ Test } \\
\hline & & $\begin{array}{l}\text { Mean } \\
\text { Rank }\end{array}$ & $\begin{array}{l}\text { Asymp. } \\
\text { Sig. (p) }\end{array}$ & $\begin{array}{l}\text { Mean } \\
\text { Rank }\end{array}$ & $\begin{array}{l}\text { Asymp. } \\
\text { Sig. (p) }\end{array}$ & \\
\hline Nationality & $\begin{array}{l}\text { Saudi } \\
\text { Sudanese } \\
\text { Indian } \\
\text { Pakistani } \\
\text { Egyptian } \\
\text { Yemeni } \\
\text { Syrian } \\
\end{array}$ & $\begin{array}{l}58.23 \\
\mathbf{6 0 . 9 2} \\
27.75 \\
42.50 \\
38.38 \\
31.58 \\
50.25 \\
\end{array}$ & .042 & $\begin{array}{l}50.15 \\
51.33 \\
35.33 \\
43.60 \\
49.20 \\
39.44 \\
33.20 \\
\end{array}$ & $.705^{* *}$ & KW Test \\
\hline Age category & $\begin{array}{l}18-25 \text { years } \\
26-35 \text { years } \\
36-45 \text { years } \\
46-55 \text { years } \\
\text { Over } 55 \text { years }\end{array}$ & $\begin{array}{l}\mathbf{6 7 . 5 0} \\
58.16 \\
59.11 \\
51.16 \\
20.94\end{array}$ & $.000^{*}$ & $\begin{array}{l}52.82 \\
57.47 \\
39.00 \\
43.72 \\
38.90\end{array}$ & $.057 * *$ & KW Test \\
\hline $\begin{array}{l}\text { Highest } \\
\text { educational } \\
\text { qualifications }\end{array}$ & $\begin{array}{l}\text { Below High School } \\
\text { High School } \\
\text { Bachelor degree } \\
\text { Master degree or above }\end{array}$ & $\begin{array}{l}23.59 \\
59.02 \\
62.17 \\
56.14 \\
\end{array}$ & $.000 *$ & $\begin{array}{l}27.92 \\
50.48 \\
50.93 \\
\mathbf{6 4 . 2 5} \\
\end{array}$ & $.002 *$ & KW Test \\
\hline Occupation & $\begin{array}{l}\text { Student } \\
\text { Private sector employee } \\
\text { Public sector employee } \\
\text { Private business } \\
\text { Retired } \\
\text { Unemployed }\end{array}$ & $\begin{array}{l}47.10 \\
56.15 \\
58.95 \\
\mathbf{6 8 . 6 3} \\
12.56 \\
37.14\end{array}$ & $.001 *$ & $\begin{array}{l}45.69 \\
44.32 \\
52.06 \\
40.67 \\
59.67 \\
19.75\end{array}$ & $.423 * *$ & KW Test \\
\hline Region & $\begin{array}{l}\text { Riyadh Region } \\
\text { Western Region } \\
\text { Eastern Region }\end{array}$ & $\begin{array}{l}\mathbf{6 5 . 5 1} \\
45.60 \\
44.53\end{array}$ & $.003^{*}$ & $\begin{array}{l}\mathbf{5 8 . 3 8} \\
38.48 \\
53.03\end{array}$ & $.004 *$ & KW Test \\
\hline
\end{tabular}

Note: (*) Statistically significant at $5 \%$ level; (**) not significant.

Furthermore, in the 'highest educational qualifications' the subgroup 'bachelor degree' occupied first place with a value of 62.17, whereas the 'below high school' group scored the lowest value at 23.59 with the $p$-value of 0.000 . The 'occupation' control variable is significant at $p$-value of 0.001 . The 'private business' category reached the highest value of 68.63, while the category 'retired' is the lowest value at 12.56. As for the control variable of 'region', the 'Riyadh region' subgroup scored the highest mean rank with a value of 65.51 , while the category 'Eastern region' occupied the last place with a value of 44.53 with the $p$-value of 0.003 .

In the case of conventional banks, as can be seen in Table 6, the control variables 
'nationality', 'age category' and 'occupation' are not statistically significant at 5\% level of significance. In contrast, two control variables 'highest educational qualifications' and 'region' are statistically significant at 5\%. In the control variable, 'highest educational qualifications' which is divided into four subgroups: 'master's degree or above' is the highest number with a value of 64.25 , while the subgroup of 'below high school' achieved the lowest value at 27.92 with the $p$-value is 0.002 . In the 'region' control variable, which is statistically significant at $p$-value of 0.004 , 'Riyadh region' obtained the highest mean rank with a value of 58.38, while 'Western Region' gained the lowest value at 38.48.

Table 7: Significance of Control Variables on the Statement: The 24/7 availability of $e$-services and e-commerce motivated me to switch over to e-commerce

\begin{tabular}{|c|c|c|c|c|c|c|}
\hline \multirow{2}{*}{$\begin{array}{c}\text { Group (Control } \\
\text { Variables) }\end{array}$} & \multirow{2}{*}{ Group Categories } & \multicolumn{2}{|c|}{$\begin{array}{l}\text { Islamic } \\
\text { Banks }\end{array}$} & \multicolumn{2}{|c|}{$\begin{array}{l}\text { Conventional } \\
\text { Banks }\end{array}$} & \multirow{2}{*}{ Test } \\
\hline & & $\begin{array}{l}\text { Mean } \\
\text { Rank }\end{array}$ & $\begin{array}{l}\text { Asymp. } \\
\text { Sig. (p) }\end{array}$ & $\begin{array}{l}\text { Mean } \\
\text { Rank }\end{array}$ & $\begin{array}{l}\text { Asymp. } \\
\text { Sig. (p) }\end{array}$ & \\
\hline Age category & $\begin{array}{l}18-25 \text { years } \\
26-35 \text { years } \\
36-45 \text { years } \\
46-55 \text { years } \\
\text { Over } 55 \text { years }\end{array}$ & $\begin{array}{l}\mathbf{6 5 . 2 5} \\
61.14 \\
57.89 \\
49.19 \\
19.84 \\
\end{array}$ & $.000 *$ & $\begin{array}{l}41.14 \\
54.74 \\
49.87 \\
39.50 \\
38.70\end{array}$ & $.203 * *$ & KW Test \\
\hline $\begin{array}{l}\text { Monthly } \\
\text { income }\end{array}$ & $\begin{array}{l}\text { Lessthan } 4001 \mathrm{SR} \\
4001-8000 \mathrm{SR} \\
8001-12000 \mathrm{SR} \\
12001-16000 \mathrm{SR} \\
16001-20000 \mathrm{SR} \\
\text { More than } 20000 \mathrm{SR}\end{array}$ & $\begin{array}{l}40.66 \\
48.91 \\
58.38 \\
65.48 \\
54.35 \\
42.69\end{array}$ & $.052 * *$ & $\begin{array}{l}29.89 \\
44.47 \\
\mathbf{6 2 . 3 8} \\
56.34 \\
34.50 \\
51.00\end{array}$ & $.003 *$ & KW Test \\
\hline $\begin{array}{l}\text { Highest } \\
\text { educational } \\
\text { qualifications }\end{array}$ & $\begin{array}{l}\text { Below High School } \\
\text { High School } \\
\text { Bachelor degree } \\
\text { Master degree or above }\end{array}$ & $\begin{array}{l}23.27 \\
57.09 \\
\mathbf{6 3 . 5 7} \\
55.32 \\
\end{array}$ & $.000 *$ & $\begin{array}{l}26.83 \\
53.61 \\
48.14 \\
\mathbf{6 6 . 0 0}\end{array}$ & $.001 *$ & KW Test \\
\hline Occupation & $\begin{array}{l}\text { Student } \\
\text { Private sector employee } \\
\text { Public sector employee } \\
\text { Private business } \\
\text { Retired } \\
\text { Unemployed }\end{array}$ & $\begin{array}{l}48.55 \\
58.75 \\
55.96 \\
\mathbf{7 0 . 3 8} \\
13.25 \\
46.14\end{array}$ & $.002 *$ & $\begin{array}{l}41.25 \\
44.92 \\
52.71 \\
61.00 \\
40.67 \\
11.25\end{array}$ & $.197 * *$ & KW Test \\
\hline Region & $\begin{array}{l}\text { Riyadh Region } \\
\text { Western Region } \\
\text { Eastern Region }\end{array}$ & $\begin{array}{l}\mathbf{6 7 . 1 9} \\
44.23 \\
44.81\end{array}$ & $.001 *$ & $\begin{array}{l}\mathbf{6 2 . 7 1} \\
37.77 \\
48.58\end{array}$ & $.000 *$ & KW Test \\
\hline
\end{tabular}

Note: (*) Statistically significant at 5\% level; (**) not significant.

Table 7 presents the results from the investigation into the identification of independent variables in relation to the statement that ' $24 / 7$ availability of e-services and e-commerce 
motivated me to switch over to e-commerce'. For this, there are five relevant control variables: 'age category', 'monthly income', 'highest educational qualifications', 'occupation' and 'region'.

For Islamic banks, as the results in table 7 show, the four control variables are statistical significant at 5\% level of significance: with regard to the 'age category', the subgroup '18-25 year-olds' is the highest mean rank with a value of 65.25 , while the lowest is the 'over 55 year-old' category with a value of 19.84 with the $p$-value of 0.000 . In the 'highest educational qualifications' control variable, the 'bachelor degree' group has the highest mean rank with a value of 63.57, while the lowest mean rank is scored by the 'below high school' subgroup with a mean rank value of 23.27 with the $p$-value is 0.000 . In the 'occupation' control variable, the highest mean value is scored by the 'private business' group at 70.38 and the lowest mean rank is the 'retired' group with a mean rank value of 13.25 with the $p$-value of 0.002. In addition, the subgroup 'Riyadh region' in the 'region' control variable scored the highest value at67.19, whilst Western region is achieved the lowest value at 44.23 with the $p$-value of the 'region' control variable is 0.001 .

In the case of the conventional banks, the 'monthly income' control variable is significant at $5 \%$ level and '8001-12000SR' group obtained the highest mean rank value at 62.38 , whereas the 'less than 4001SR' category achieved the lowest mean rank with a value of 29.89 with the $p$-value is 0.003 . The 'highest educational qualifications' control variable has a $p$-value of 0.001, which expresses the differing views held on this subject by the participants: the group 'master's degree or above' recorded the highest mean rank at 66.00, and the 'below high school' category achieved the lowest mean rank with a value of 26.83 . Furthermore, the subgroup 'Riyadh region' in the 'Region' control variable recorded the highest value at 62.71 , whilst the lowest value is recorded for 'Western region' at 37.77 with the $p$-value of 0.000 .

As can be seen in Table 8, the first statistically significant control variable at the $5 \%$ level in the Islamic banks group is 'nationality'; accordingly, 'Saudi' nationalities scored the highest mean rank value of 59.95, while the lowest mean rank is for 'Indian' nationalities at 28.67 with the $p$-value of 0.023 . In the 'age category' control variable, the subgroup '26-35 year-olds' recorded the highest mean rank value at 67.16, whilst the 'over 55 year-old' group scored the lowest with a value of 19.06 with the $p$-value of 0.000 .In the 'highest educational qualifications' case, 'high school' degree with a value of 60.98 is achieved the highest mean rank, whereas the 'below high school' subgroup scored the lowest value at 25.73 with the $p$-value of 0.000 . 


\section{Macrothink}

Table 8: Significance of Control Variables on the Statement: Website design of the bank motivated me to use internet banking

\begin{tabular}{|c|c|c|c|c|c|c|}
\hline \multirow{2}{*}{$\begin{array}{c}\text { Group (Control } \\
\text { Variables) }\end{array}$} & \multirow{2}{*}{ Group Categories } & \multicolumn{2}{|c|}{$\begin{array}{c}\text { Islamic } \\
\text { Banks }\end{array}$} & \multicolumn{2}{|c|}{$\begin{array}{c}\text { Conventional } \\
\text { Banks }\end{array}$} & \multirow{2}{*}{ Test } \\
\hline & & $\begin{array}{l}\text { Mean } \\
\text { Rank }\end{array}$ & $\begin{array}{l}\text { Asymp. } \\
\text { Sig. (p) }\end{array}$ & $\begin{array}{l}\text { Mean } \\
\text { Rank }\end{array}$ & $\begin{array}{l}\text { Asymp. } \\
\text { Sig. (p) }\end{array}$ & \\
\hline Nationality & $\begin{array}{l}\text { Saudi } \\
\text { Sudanese } \\
\text { Indian } \\
\text { Pakistani } \\
\text { Egyptian } \\
\text { Yemeni } \\
\text { Syrian } \\
\end{array}$ & $\begin{array}{l}\mathbf{5 9 . 9 5} \\
45.25 \\
28.67 \\
36.00 \\
38.06 \\
36.33 \\
44.38 \\
\end{array}$ & $.023 *$ & $\begin{array}{l}50.66 \\
49.00 \\
44.83 \\
44.80 \\
45.60 \\
37.31 \\
28.00 \\
\end{array}$ & $.535 * *$ & KW Test \\
\hline Age category & $\begin{array}{l}18-25 \text { years } \\
26-35 \text { years } \\
36-45 \text { years } \\
46-55 \text { years } \\
\text { Over } 55 \text { years }\end{array}$ & $\begin{array}{l}57.05 \\
\mathbf{6 7 . 1 6} \\
59.15 \\
39.81 \\
19.06\end{array}$ & $.000^{*}$ & $\begin{array}{l}39.45 \\
\mathbf{5 5 . 8 2} \\
52.81 \\
39.09 \\
30.20\end{array}$ & $.023 *$ & KW Test \\
\hline $\begin{array}{l}\text { Monthly } \\
\text { income }\end{array}$ & $\begin{array}{l}\text { Lessthan } 4001 \mathrm{SR} \\
4001-8000 \mathrm{SR} \\
8001-12000 \mathrm{SR} \\
12001-16000 \mathrm{SR} \\
16001-20000 \mathrm{SR} \\
\text { More than } 20000 \mathrm{SR} \\
\end{array}$ & $\begin{array}{l}43.18 \\
45.06 \\
60.59 \\
60.63 \\
62.31 \\
39.94 \\
\end{array}$ & $.081 * *$ & $\begin{array}{l}34.58 \\
42.48 \\
55.91 \\
53.68 \\
\mathbf{6 4 . 8 3} \\
62.50\end{array}$ & $.045^{*}$ & KW Test \\
\hline $\begin{array}{l}\text { Highest } \\
\text { educational } \\
\text { qualifications }\end{array}$ & $\begin{array}{l}\text { Below High School } \\
\text { High School } \\
\text { Bachelor degree } \\
\text { Master degree or above }\end{array}$ & $\begin{array}{l}25.73 \\
\mathbf{6 0 . 9 8} \\
60.03 \\
56.43\end{array}$ & $.000 *$ & $\begin{array}{l}22.31 \\
51.95 \\
49.63 \\
\mathbf{7 6 . 5 0}\end{array}$ & $.000^{*}$ & KW Test \\
\hline Occupation & $\begin{array}{l}\text { Student } \\
\text { Private sector employee } \\
\text { Public sector employee } \\
\text { Private business } \\
\text { Retired } \\
\text { Unemployed }\end{array}$ & $\begin{array}{l}72.60 \\
54.73 \\
54.45 \\
54.50 \\
16.63 \\
41.79 \\
\end{array}$ & $.003 *$ & $\begin{array}{l}46.63 \\
43.63 \\
55.03 \\
25.50 \\
44.83 \\
16.75 \\
\end{array}$ & $.108 * *$ & KW Test \\
\hline Region & $\begin{array}{l}\text { Riyadh Region } \\
\text { Western Region } \\
\text { Eastern Region }\end{array}$ & $\begin{array}{l}61.24 \\
47.65 \\
47.72\end{array}$ & $.075^{* *}$ & $\begin{array}{l}\mathbf{6 0 . 8 2} \\
39.82 \\
46.60\end{array}$ & $.004 *$ & KW Test \\
\hline
\end{tabular}

Note: $(*)$ Statistically significant at $5 \%$ level; $(* *)$ not significant.

In the 'occupation' control variable the highest value is for the 'student' category at 72.60 and the lowest value is for the 'retired' group with a value of 16.63 with the $p$-value of 0.003 . With regard to conventional banks, the 'age category' is statistically significant at $5 \%$ level of significance with the $p$-value of 0.023: the subgroup '26-35 year-olds' achieved the highest 
value at 55.82, while the 'over 55 year-old' category scored the lowest mean rank at 30.20. Within the 'monthly income' control variable, the '16001-20000SR' category registered the highest value at 64.83, whereas the 'less than 4001SR' group recorded the lowest value with a value of 34.58 with the $p$-value of 0.045 . For the control variable 'highest educational qualifications', the 'master's degree or above' group reached the highest mean rank at 76.50, while the lowest mean rank was scored by 'below high school' category at 22.31 with the $p$-value of 0.000 . The last significant control variable in relation to this statement is 'region' with a $p$-value of 0.004 . In this category 'Riyadh region' scored the highest mean rank value of 60.82 , while the lowest is 'Western region' with a mean ranking value of 39.82 .

Table 9: Significance of Control Variables on the Statement: Changing nature of shopping as a life style necessitates the use e-banking services and e-commerce

\begin{tabular}{|c|c|c|c|c|c|c|}
\hline \multirow{2}{*}{$\begin{array}{c}\text { Group (Control } \\
\text { Variables) }\end{array}$} & \multirow{2}{*}{ Group Categories } & \multicolumn{2}{|c|}{$\begin{array}{c}\text { Islamic } \\
\text { Banks }\end{array}$} & \multicolumn{2}{|c|}{$\begin{array}{c}\text { Conventional } \\
\text { Banks }\end{array}$} & \multirow{2}{*}{ Test } \\
\hline & & $\begin{array}{l}\text { Mean } \\
\text { Rank }\end{array}$ & $\begin{array}{l}\text { Asymp. } \\
\text { Sig. (p) }\end{array}$ & $\begin{array}{l}\text { Mean } \\
\text { Rank }\end{array}$ & $\begin{array}{l}\text { Asymp. } \\
\text { Sig. (p) }\end{array}$ & \\
\hline Age category & $\begin{array}{l}18-25 \text { years } \\
26-35 \text { years } \\
36-45 \text { years } \\
46-55 \text { years } \\
\text { Over } 55 \text { years }\end{array}$ & $\begin{array}{l}52.80 \\
62.06 \\
66.94 \\
43.63 \\
15.91\end{array}$ & $.000 *$ & $\begin{array}{l}41.77 \\
\mathbf{5 7 . 4 8} \\
47.00 \\
45.81 \\
26.85\end{array}$ & $.023 *$ & KW Test \\
\hline $\begin{array}{l}\text { Monthly } \\
\text { income }\end{array}$ & $\begin{array}{l}\text { Lessthan } 4001 \mathrm{SR} \\
4001-8000 \mathrm{SR} \\
8001-12000 \mathrm{SR} \\
12001-16000 \mathrm{SR} \\
16001-20000 \mathrm{SR} \\
\text { More than } 20000 \mathrm{SR} \\
\end{array}$ & $\begin{array}{l}45.38 \\
37.68 \\
60.09 \\
51.65 \\
\mathbf{7 2 . 9 6} \\
59.44 \\
\end{array}$ & .015 & $\begin{array}{l}40.37 \\
41.98 \\
51.59 \\
50.98 \\
66.33 \\
70.75 \\
\end{array}$ & $.144 * *$ & KW Test \\
\hline $\begin{array}{l}\text { Highest } \\
\text { educational } \\
\text { qualifications }\end{array}$ & $\begin{array}{l}\text { Below High School } \\
\text { High School } \\
\text { Bachelor degree } \\
\text { Master degree or above }\end{array}$ & $\begin{array}{l}29.09 \\
54.67 \\
55.32 \\
\mathbf{7 6 . 6 4}\end{array}$ & $.000 *$ & $\begin{array}{l}29.28 \\
40.82 \\
57.97 \\
\mathbf{7 0 . 2 5}\end{array}$ & $.000 *$ & KW Test \\
\hline Occupation & $\begin{array}{l}\text { Student } \\
\text { Private sector employee } \\
\text { Public sector employee } \\
\text { Private business } \\
\text { Retired } \\
\text { Unemployed }\end{array}$ & $\begin{array}{l}\mathbf{6 4 . 7 0} \\
49.44 \\
60.25 \\
26.13 \\
13.75 \\
48.50\end{array}$ & $.000 *$ & $\begin{array}{l}42.63 \\
42.91 \\
\mathbf{5 6 . 0 5} \\
27.00 \\
49.67 \\
17.25\end{array}$ & $.070 * *$ & KW Test \\
\hline Region & $\begin{array}{l}\text { Riyadh Region } \\
\text { Western Region } \\
\text { Eastern Region }\end{array}$ & $\begin{array}{l}53.73 \\
55.32 \\
44.36\end{array}$ & .388 & $\begin{array}{l}\mathbf{5 7 . 9 6} \\
44.00 \\
40.90\end{array}$ & $.037 *$ & KW Test \\
\hline
\end{tabular}

Note: (*) Statistically significant at $5 \%$ level; $(* *)$ not significant. 


\section{Ml Macrothink}

Table 9 shows the results of the independent variables in relation to the statement 'Changing nature of shopping as a life style necessitates using e-services banking and e-commerce'. For Islamic banks, the control variable 'age category' is statistically significant at the $5 \%$ level with ap-value of 0.000; the '36-45 year-olds' group recorded the highest mean rank value at 66.94, while the lowest value of 15.91 is scored by the 'over 55 year-old' category, which underlines a difference in the responses to this statement. The control variable 'monthly income' has a $p$-value of 0.015 : the '16001-20000SR' category scored the highest mean rank value at 72.96, whereas the lowest mean rank is scored by the '4001-8000SR' subgroup with a figure of 37.68. The 'highest educational qualifications' control variable with a $p$-value of 0.000 resulted in the highest mean rank (76.64) with the 'master's degree or above' group, while the lowest value is the 'below high school' category at 29.09. The 'occupation' control variable is statistically significant at the level of $5 \%$, with a $p$-value of 0.000 . The highest value went to the 'student' group at 64.70 and the lowest figure went to the 'retired' category with a value of 13.75 .

As can be seen in Table 9, for conventional banks the 'age category' control variable with a $p$-value of 0.023 , resulted in the highest value going to the group '26-35 year-olds' category and the lowest value is for the 'over 55 years-old' group at 26.85. In addition, in the control variable 'highest educational qualifications' with a $p$-value of 0.000 , the highest rank is taken by the 'master's degree or above' group with a value of 70.25, while the 'below high school' group rank the lowest at 29.28. Furthermore, in the 'Region' control variable with a $p$-value of 0.037 , the highest value is obtained by 'Riyadh region' at 57.96, while the lowest mean rank is by 'Eastern region' with a value of 40.90 .

Table 10 shows the results of significant independent variables in relation to the statement 'E-payment method encouraged me to adopt e-commerce'. In the table three control variables that are highlighted are: 'age category', 'highest educational qualifications', and 'occupation'.

As can be seen from Table 10, for the Islamic banks, the 'age category' control variable is significant at 5\% level of significance with $p$-value of 0.000 : accordingly, the ' $18-25$ year-olds' group secured the highest mean rank with a value of 73.30, while the lowest mean rank is achieved by the 'over 55 year-old' subgroup with a value of 22.66. With regard to the 'highest educational qualifications' control variable the 'high school' subgroup is the highest value at 62.15 , whilst the lowest number is for the 'below high school' subgroup with a value of 27.27. The $p$-value for this variable is 0.000 . In addition, the results of the 'occupation' control variable shows thatthe 'public sector employee' category scored the highest mean rank at 60.37, whereas the lowest is the 'retired' group with a value of 19.81 with $p$-value of 0.010 . 


\section{I Macrothink}

Table 10: Significance of Control Variables on the Statement: E-Payment method encouraged me to adopt e-commerce

\begin{tabular}{|c|c|c|c|c|c|c|}
\hline \multirow{2}{*}{$\begin{array}{c}\text { Group (Control } \\
\text { Variables) }\end{array}$} & \multirow{2}{*}{ Group Categories } & \multicolumn{2}{|c|}{$\begin{array}{l}\text { Islamic } \\
\text { Banks }\end{array}$} & \multicolumn{2}{|c|}{$\begin{array}{c}\text { Conventional } \\
\text { Banks }\end{array}$} & \multirow{2}{*}{ Test } \\
\hline & & $\begin{array}{l}\text { Mean } \\
\text { Rank }\end{array}$ & $\begin{array}{l}\text { Asymp. } \\
\text { Sig. (p) }\end{array}$ & $\begin{array}{l}\text { Mean } \\
\text { Rank }\end{array}$ & $\begin{array}{l}\text { Asymp. } \\
\text { Sig. (p) }\end{array}$ & \\
\hline Age category & $\begin{array}{l}18 \text { - } 25 \text { years } \\
26 \text { - } 35 \text { years } \\
36 \text { - } 45 \text { years } \\
46 \text { - } 55 \text { years } \\
\text { Over } 55 \text { years }\end{array}$ & $\begin{array}{l}73.30 \\
54.67 \\
61.89 \\
48.75 \\
22.66 \\
\end{array}$ & $.000 *$ & $\begin{array}{l}49.45 \\
56.00 \\
43.44 \\
44.81 \\
33.85 \\
\end{array}$ & $.145^{* *}$ & KW Test \\
\hline $\begin{array}{l}\text { Highest } \\
\text { educational } \\
\text { qualifications }\end{array}$ & $\begin{array}{l}\text { Below High School } \\
\text { High School } \\
\text { Bachelor degree } \\
\text { Master degree or above }\end{array}$ & $\begin{array}{l}27.27 \\
62.15 \\
57.48 \\
60.29\end{array}$ & $.000 *$ & $\begin{array}{l}19.78 \\
53.18 \\
52.29 \\
\mathbf{6 5 . 5 0}\end{array}$ & $.000 *$ & KW Test \\
\hline Occupation & $\begin{array}{l}\text { Student } \\
\text { Private sector employee } \\
\text { Public sector employee } \\
\text { Private business } \\
\text { Retired } \\
\text { Unemployed }\end{array}$ & $\begin{array}{l}49.85 \\
51.54 \\
60.37 \\
49.63 \\
19.81 \\
41.21\end{array}$ & $.010 *$ & $\begin{array}{l}34.13 \\
42.42 \\
\mathbf{5 8 . 5 0} \\
30.50 \\
41.67 \\
19.75\end{array}$ & $.015 *$ & KW Test \\
\hline
\end{tabular}

Note: (*) Statistically significant at $5 \%$ level; $(* *)$ not significant.

In terms of the conventional banks in the control variable 'highest educational qualifications' the 'master's degree or above' group registered the highest mean rank value at 65.50 , while the lowest value is with the 'below high school' group with a value of 19.78 and with a $p$-value of 0.000. As regards to the 'occupation' control variable, the highest mean rank is for the 'public sector employee' at 58.50 and the lowest mean rank (19.75) is scored by the 'unemployed' subgroup with the $p$-value of 0.015 . The results point to diverging views amongst the participants regarding the encouragement of e-payment methods to adopt e-commerce regardless of bank type.

As regards to the motivational source statement that 'Banks provide information to their customers about the use of online banking, ATMs and others', the findings are presented in Table 11. 


\section{I Macrothink}

Table 11: Significance of Control Variables on the Statement: Banks provide Information to their customers about the use of online Banking, ATMs and others

\begin{tabular}{|c|c|c|c|c|c|c|}
\hline \multirow{2}{*}{$\begin{array}{l}\text { Group } \\
\text { (Control } \\
\text { Variables) }\end{array}$} & \multirow{2}{*}{ Group Categories } & \multicolumn{2}{|c|}{$\begin{array}{l}\text { Islamic } \\
\text { Banks }\end{array}$} & \multicolumn{2}{|c|}{$\begin{array}{l}\text { Conventional } \\
\text { Banks }\end{array}$} & \multirow[b]{2}{*}{ Test } \\
\hline & & $\begin{array}{l}\text { Mea } \\
\mathrm{n} \\
\text { Ran } \\
\mathrm{k}\end{array}$ & $\begin{array}{l}\text { Asym } \\
\text { p. Sig. } \\
\text { (p) }\end{array}$ & $\begin{array}{l}\text { Mea } \\
\mathrm{n} \\
\text { Ran } \\
\mathrm{k}\end{array}$ & $\begin{array}{l}\text { Asym } \\
\text { p. Sig. } \\
\text { (p) }\end{array}$ & \\
\hline Region & $\begin{array}{l}\text { Riyadh Region } \\
\text { Western Region } \\
\text { Eastern Region }\end{array}$ & $\begin{array}{l}\mathbf{6 2 . 1} \\
\mathbf{2} \\
45.9 \\
4 \\
50.5 \\
8\end{array}$ & $.035 *$ & $\begin{array}{l}55.6 \\
1 \\
42.3 \\
7 \\
47.9 \\
5\end{array}$ & $\begin{array}{l}.104 * \\
*\end{array}$ & KW Test \\
\hline
\end{tabular}

Note: $(*)$ Statistically significant at $5 \%$ level; $(* *)$ not significant.

According to which only the 'Region' control variable is statistically significant. For the Islamic banks customers in relation to the statement, at the 5\% significance level with the $p$-value of 0.035 .The highest value is registered by 'Riyadh region' with 62.12 , while the lowest mean rank with a value of 45.94 is obtained by 'Western region'. It should be noted that all other independent variables in the case of conventional banks is statistically founded to be not significant.

The findings from the application of K-W and MW-U tests in table 12, shows that gender and nationality were found not to be significant for the majority of control variables for both banking types in customers' motivation in e-commerce and e-banking services. The Age category control variable demonstrate interesting findings as the 18-25 subgroup has been the most frequent for Islamic banks, compared to that of the conventional banks with the 26-35 years-old subgroup in 2 out of 6 cases. In addition, the Monthly income control variable is not significant for the majority of participants in the Islamic and Conventional banks.

With regard to the Highest educational qualifications control variable, in half cases the degree holders category have been found significant in Islamic banks, and in most cases in conventional banks the Master degree or above holders category have been found significant. The occupation control variable, majority of cases no subgroup was found to be dominantly significant. On the other hand, the Region control variable with Riyadh region was appeared to be significant in a large number of cases for the two groups of banks. 
Table 12: The Highest Significant Subcategories among the Control Variables on Respondents' Motivation in E-Commerce and E-Banking Services.

\begin{tabular}{|c|c|c|c|c|c|c|c|c|c|c|}
\hline \multirow[b]{2}{*}{ Statement } & \multicolumn{2}{|c|}{ Age category } & \multicolumn{2}{|c|}{ Monthly income } & \multicolumn{2}{|c|}{ educational } & \multicolumn{2}{|c|}{ Occupation } & \multicolumn{2}{|c|}{ Region } \\
\hline & E. & 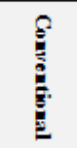 & E. & है & E. & 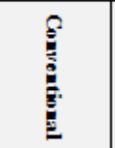 & פ. & 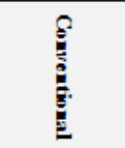 & हृ. & 象 \\
\hline $\begin{array}{l}\text { 1) The ease of the use of e- } \\
\text { banking services motivated } \\
\text { me to switch over to e- } \\
\text { commerce }\end{array}$ & $\begin{array}{l}18-25 \\
\text { years }\end{array}$ & None & None & None & $\begin{array}{l}\text { Bachel } \\
\text { or } \\
\text { degree }\end{array}$ & $\begin{array}{c}\text { Master } \\
\text { degree } \\
\text { or above }\end{array}$ & $\begin{array}{c}\text { Private } \\
\text { business }\end{array}$ & None & $\begin{array}{l}\text { Riyadh } \\
\text { Region }\end{array}$ & $\begin{array}{l}\text { Riyadh } \\
\text { Region }\end{array}$ \\
\hline $\begin{array}{l}\text { 2) The } 24 / 7 \text { availability of e- } \\
\text { services and e-commerce } \\
\text { motivated me to switch over } \\
\text { to e-commerce }\end{array}$ & $\begin{array}{l}18-25 \\
\text { years }\end{array}$ & None & None & $\begin{array}{l}8001- \\
12000 \\
\text { SR }\end{array}$ & $\begin{array}{l}\text { Bachel } \\
\text { or } \\
\text { degree }\end{array}$ & $\begin{array}{c}\text { Master } \\
\text { degree } \\
\text { or above }\end{array}$ & $\begin{array}{c}\text { Private } \\
\text { business }\end{array}$ & None & $\begin{array}{l}\text { Riyadh } \\
\text { Region }\end{array}$ & $\begin{array}{l}\text { Riyadh } \\
\text { Region }\end{array}$ \\
\hline $\begin{array}{l}\text { 3) Website design of bank } \\
\text { motivated me to use Intemet } \\
\text { Banking }\end{array}$ & $\begin{array}{l}26-35 \\
\text { years }\end{array}$ & $\begin{array}{l}26-35 \\
\text { years }\end{array}$ & None & $\begin{array}{l}16001- \\
20000 \\
\text { SR }\end{array}$ & $\begin{array}{l}\text { High } \\
\text { school }\end{array}$ & $\begin{array}{c}\text { Master } \\
\text { degree } \\
\text { or above }\end{array}$ & Student & None & None & $\begin{array}{l}\text { Riyadh } \\
\text { Region }\end{array}$ \\
\hline $\begin{array}{l}\text { 4) Changing nature of shopping } \\
\text { as a life style necessitates } \\
\text { using e-banking services and } \\
\text { e-commerce }\end{array}$ & $\begin{array}{l}36-45 \\
\text { years }\end{array}$ & $\begin{array}{l}26-35 \\
\text { years }\end{array}$ & $\begin{array}{l}16001- \\
20000 \\
\text { SR }\end{array}$ & None & $\begin{array}{l}\text { Master } \\
\text { degree } \\
\text { or } \\
\text { above }\end{array}$ & $\begin{array}{c}\text { Master } \\
\text { degree } \\
\text { or above }\end{array}$ & Student & $\begin{array}{c}\text { Public } \\
\text { sector } \\
\text { employee }\end{array}$ & None & $\begin{array}{l}\text { Riyadh } \\
\text { Region }\end{array}$ \\
\hline $\begin{array}{l}\text { 5) E-payment method } \\
\text { encouraged me to a dopt e- } \\
\text { commerce. }\end{array}$ & $\begin{array}{l}18-25 \\
\text { years }\end{array}$ & None & None & None & $\begin{array}{c}\text { High } \\
\text { school }\end{array}$ & $\begin{array}{c}\text { Master } \\
\text { degree } \\
\text { or above }\end{array}$ & $\begin{array}{c}\text { Public } \\
\text { sector } \\
\text { employee }\end{array}$ & $\begin{array}{c}\text { Public } \\
\text { sector } \\
\text { employee }\end{array}$ & None & None \\
\hline $\begin{array}{l}\text { 6) Banks provide information to } \\
\text { their customers about the use } \\
\text { of online banking, ATMs and } \\
\text { others }\end{array}$ & None & None & None & None & None & None & None & None & $\begin{array}{l}\text { Riyadh } \\
\text { Region }\end{array}$ & None \\
\hline
\end{tabular}

It can be argued that in consideration of the respondents' viewpoints about motivation in e-commerce and e-services and the statistical inferences, the Islamic and conventional banks tend to perform rather equally. One conclusion which can be drawn from table 18 is that the Islamic banks customers' motivation in Saudi banking is much more positive than those of the conventional banks.

\section{Discussion and Conclusion}

This paper has provided a platform for collecting and analysing the views of the participants about the respondents' viewpoints about motivation in e-commerce and e-services in Islamic and conventional Saudi banks. In order to capture the perception of the two types of banks customers, a questionnaire was designed primarily around the awareness in e-commerce and e-banking services. After a careful consideration, 6 major questions were developed and presented in the questionnaire. Using a sample of 250 participants, the study received a sum of 198 (104 Islamic banks; and 94 Conventional banks) - a rather respectable response rate of $79 \%$.

In this paper a survey questionnaire results have been presented with supporting interpretation of the statistical findings about the respondents' viewpoints about motivation to deal, use and practicing e-commerce in Islamic and conventional banks of Saudi Arabia.

The initial information from the results present all mean values and ranking of customers' viewpoints about motivation in e-commerce and e-services for the Islamic and conventional banks. As was shown in descriptive section, the results of assessing customers' motivation to engage with e-commerce, the customers have chosen the same preference order for only 1 of 6 statements, and for the rest the mean values are dissimilar. Moreover, the findings of the inferential statistical from a detailed analysis on determining the significance of the 
differences in the opinions expressed in relation to a number of questions and statements were presented through a number of control variables along with the use of non-parametric tests, including the Independent Samples Kruskal-Wallis Test (KW Test) as well as the Mann-Whitney U Test (MWU Test). The findings of the tests were presented on the basis of the $5 \%$ significance level.

The viewpoints of customers' motivation to engage with e-commerce and practicing e-commerce, the analysis so far indicates, that both gender and nationality are not significant for all of control variables for both banking types. For the Age category control variable, demonstrate interesting findings as the 18-25 subgroup has been the most frequent for Islamic banks, compared to that of the conventional banks with the 26-35 years-old subgroup. In addition, the Monthly income control variable is found not to be significant for the majority of participants in the Islamic and Conventional banks. With regard to the Highest educational qualifications control variable, in half cases the degree holders category have been found significant in Islamic banks, and in most cases in conventional banks the Master degree or above holders category have been found significant. As for the occupation control variable, majority of cases the subgroup students have turned out to be not significant. On the other hand, the Region control variable with Riyadh region appeared to be significant in a large number of cases for the two groups of banks. It can be argued that in consideration of the respondents' viewpoints about motivation in e-commerce and e-services and the statistical inferences, the Islamic and conventional banks tend to perform rather equally.

As final remarks for this paper, it is fair to argue that there are a number of similarities that were found between Islamic and conventional banks based on the customers' motivation. In both banks the research has found that gender, nationality, monthly income and occupation are insignificant, whilst age, qualifications and regions were found to be significant. On the basis of the findings, the study recommends that Saudi banks should provide their customers with more information about the benefits of using e-banking services and dealing with e-commerce.

\section{References}

Ahmed, M.S. (2009), Electronic Marketing, Dar Al Meseria, Aman.

Al Saud, A. F. and Abdallah, A. E. (2004). A Framework for Analyzing and Comparing E-Banking Capabilities. Paper presented at Iadis International Conference E-Society, on $16^{\text {th }}$ $19^{\text {th }}$ July 2004 , Spain.

Al-Gahtani, S. S., Hubona, G. S. and Wang, J. (2007) "Information technology (IT) in Saudi Arabia: Culture and the acceptance and use of IT", Information \& Management, 44(8), 681-691.

Al-Maliki, S. Q. (2013), "Information and Communication Technology (ICT) Investment in the Kingdom of Saudi Arabia: Assessing Strengths and Weaknesses", Journal of Organizational Knowledge Management, Vol. 2013.

Al-Somali, S. A., Gholami, R. and Ben, C. (2009), “An Investigation into The acceptance of 
Online Banking in Saudi Arabia”, Technovation, Vol. 29, pp. 130-141.

Al-Somali, S. A.;Gholami, R. and Clegg, B. (2011) "An Investigation into the Adoption of Electronic Commerce among Saudi Arabian SMEs". Journal of Electronic Commerce in Organizations, 9(2), 41-65.

Al-Wadi, M. H. Samhan, H. M. Samhan, S. A. (2014), Money and Banking, Dar Almasirah, Amman.

Bahaddad, A. A.; Houghton, L. and Drew, S. (2013). "Attracting Customer in Saudi Arabia to Buy from Your Business Online”. International Journal of Business and Management, 8(7), 65-81.

Bankscope Database (2015) Available at: <URL: https://bankscope.bvdinfo.com//> Access Date $6^{\text {th }}$ Jan, 2015.

Ben-Jadeed, M. and Molina, A. (2004). "The Emergence and Evolution of e-Banking in Saudi Arabia: The Case of Samba Financial Group," Frontiers of E-Business Research, Vol. 1, 90-106.

Bidgoli, H. (2002), Electronic Commerce: Principles and Practice, Academic Press, San Diego.

Chaffey, D. (2009),E-business and e-commerce management: strategy, implementation and practice, Harlow, England, FT Prentice Hall.

Chan, H. Lee, R. Dillon, T. and Chang, E. (2001), E-Commerce Fundamentals and Applications, John Wiley \& Sons New, York.

Conley, C. (2007). Peak How Great Companies Get Their Mop from Maslow. San Francisco: Jossey-Bass.

Cronbach, L. J. (1951), “Coefficient alpha and the internal structure of tests", Psychometrika, Vol. 16 No. 3, pp. 297-334.

Digital Portal. (2014). [European Travel Commission] Available at: <URL: http://etc-digital.org/> Access Date $4^{\text {th }}$ Jan, 2015.

E-Banking Rules. (2010). [The Saudi Arabian Monetary Agency (SAMA)] Available at:<URL: http://www.sama.gov.sa/ > Access Date $18^{\text {th }}$ Nov, 2012.

E-commerce: evolution or revolution in the fast-moving consumer goods world?.(2014/ August).[Nielsen] Available at:<URL:www.nielsen.com> Access Date: 22 Oct, 2014.

Elseoud, M. S. A. (2014). "Electronic Commerce and Economic Growth in Saudi Arabia".International Journal of Economics Commerce and Management, 2 (5), 1-16.

Fujun, L., Hutchinson, J. Li, D. and Bai, C. (2007), “An empirical assessment and application of SERVQUAL in mainland China's mobile communications industry", The International Journal of Quality \& Reliability Management, Vol. 24 No. 3, pp 244-26. 


\section{I Macrothink}

Journal of Public Administration and Governance ISSN 2161-7104 2015, Vol. 5, No. 3

Grandón, E. E.; Nasco, S. A. and Mykytyn Jr, P. P. (2011).“Comparing Theories to Explain E-Commerce Adoption”.Journal of Business Research, 64(3), 292-298.

Guide to Measuring the Information Society. (2011). [The Organisation for Economic Co-operation and Development (OECD)] Available at:<URL:http://www.oecd.org/> Access Date: $15^{\text {th }}$ Sep, 2014.

ICT Market Study. (2010). [The Communications and Information Technology Commission in S. A] Available at: <URL: http: //www.citc.gov.sa> Access Date $4^{\text {th }}$ July, 2011.

Internet Usage. (2014). [European Travel Commission] Available at:<URL:http://etc-digital.org/> Access Date: 23 Oct, 2014.

IT Report. (2010). [The Communications and Information Technology Commission in S. A] Available at: <URL: http: //www.citc.gov.sa> Access Date $14^{\text {th }}$ July, 2012.

Jebur, H., Gheysari, H. and Roghanian, P. (2012), "E-Commerce Reality and Controversial Issue", International Journal of Fundamental Psychological and Social sciences, Vol. 2 No. 4, pp.74-79.

Kalakota, R. and Whinston, A. B. (1997),Electronic commerce: a manager's guide, Reading, Mass, Addison-Wesley.

Kolsaker, A. and Payne, C. (2002). "Engendering Trust in E-Commerce: A Study of Gender-Based Concerns". Marketing Intelligence \& Planning, 20(4), 206-214.

Kumbhar, V. M. (2011), "Factors Affecting on Customers' Satisfaction in E-Banking: Some Evidences From Indian Banks", Management Research and Practice, Vol. 3 No. 4, pp. 1-14.

Leiner, B. M., Cerf, V. G. Clark, D. D. Kahn, R. E. Kleinrock, L. Lynch, D. C. Postel, J. Roberts, L. and Wolff, S. (2009), "A Brief History of the Internet", COMPUTER COMMUNICATION REVIEW, Vol. 39 No. 5, pp. 22-31.

Meziane, F. and Kasiran, M. K. (2008). "Evaluating Trust in Electronic Commerce: A Study Based on the Information Provided on Merchants' website". Journal of the Operational Research Society, 59 (4), 464-472.

Nitsure, R.R. (2003), "E-banking: Challenges and Opportunities”, Economic and Political Weekly, Vol. 38 No. 51, pp. 5377-5381.

OECD. Publishing. (2011). OECD Guide to Measuring the Information Society.Organisation for Economic Co-operation and Development. Available at:<URL:http://www.oecd.org/> Access Date: 15 Sep, 2014.

Oliver, F.R. (1964). What Do Statistics Show. London: MacMillan.

SAMA Annual Report. (2011). [The Saudi Arabian Monetary Agency (SAMA)] Available at:<URL: http://www.sama.gov.sa/ > Access Date: $6^{\text {th }}$ Mar, 2012.

SAMA Annual Report. (2013). [The Saudi Arabian Monetary Agency (SAMA)] Available at:<URL: http://www.sama.gov.sa/ > Access Date: $6^{\text {th }}$ Nov, 2014. 


\section{Macrothink}

Journal of Public Administration and Governance ISSN 2161-7104 2015, Vol. 5, No. 3

Scheaffer, R.; Mendenhall III, W.; Ott, R. and Gerow, K. (2012).Elementary Survey Sampling ( $7^{\text {th }}$ ed.). Boston: Brooks-Cole.

Sohail, M. S. and Shaikh, N. M. (2008), "Internet banking and quality of service: Perspectives from a developing nation in the Middle East", Online Information Review, Vol. 32 No 1, pp. 58-72.

Suh, B. and Han, 1. (2003), "The Impact of Customer Trust and Perception of Security Control on the Acceptance of Electronic Commerce", International Journal of Electronic Commerce, Vol. 7 No. 3, pp.135-161.

Total Population 2014. (2014). [Saudi Central Department of Statistics and Information] Available at: <URL: http:// http://www.cdsi.gov.sa/>Access Date 15 ${ }^{\text {th }}$ Jan, 2015.

Yasen, G. S. and Al-alaq, A. B. (2009). E-Commerce. Amman: Dar Al-Manahej. 